\title{
$\triangle M E$

\section{Study on the innovation process in precision agriculture using patent mapping using NPK sensors in the production of fertilizers}

\author{
MARCEllo Reis $^{1,2}$, Patricia Reis ${ }^{3}$, MARIa Elisa Martinez $^{3}$, YOUlia Lopes $^{1}$, \\ Glendo GUimarães $^{1}$, Alexandre ManiÇOBA DE Oliveira ${ }^{4}$ \\ ${ }^{1}$ Instituto Federal de Educação, Ciência e Tecnologia do Ceará - IFCE, Brazil; ${ }^{2}$ Meteora Aceleradora, Brazil; \\ ${ }^{3}$ National Institute of Industrial Property - INPI, Brazil \\ ${ }^{4}$ Federal Institute of Education, Science and Technology of São Paulo - IFSP, Brazil \\ <mcarv.reis@gmail.com>,<pcreis@inpi.gov.br>.<melisa@inpi.gov.br> \\ <youlia.lopeslima@gmail.com>,<glendofreitas@ifce.edu.br>,<amanicoba@ifsp.edu.br>
}

DOI: http://dx.doi.org/10.21439/jme.v4i1.87

Received: 12 July 2020. Accepted: 18 Mar. 2021

\begin{abstract}
With the constant population growth, Agroindustry has sought to innovate in its products and processes, with innovation and precision agriculture in the use of NPK fertilizers, and the determination of the concentrations of NPK present in the soil, makes it necessary for the correction of such levels in order to obtain greater soil efficiency and crop productivity, this adopted practice requires the use of sensors both in the bio manager and in the soil for the result to be really valid. There is a need to evaluate the scenario in which the NPK sensors developed to date are inserted in order to contribute to the knowledge in this area of study. One of the ways to carry out such an evaluation is through the information contained in the patent documents, the objective of this article. With the search for these documents, 95 patent documents were selected after reading and analyzing the abstracts, where the presence in both the soil and the soil and in the bio manager, we had 66\% of the cases, and China (96\%), which is the country that consumes the most fertilizers, as parents that most protects its innovations with emphasis on the Jiangsu region.
\end{abstract}

Keywords: Patent Mapping. Sensors. NPK Fertilizers.

\section{Introduction}

There is an increase in the demand for food and agriculture in the world due to the population growth that increases the consumption of resources, thus making the activities related to agriculture and food economically of great relevance (SILVA; FERNANDES, 2015, LOPES; LOWERY; PEROBA, 2016). Thus, it is necessary to apply processes that make this sector more efficient, such as, for example, increasing productivity and reducing production costs, which can be through the reduction of consumption of inputs (AMARAL; MOLIN 2011).

Agricultural productivity is directly linked to soil fertility. As agricultural crops grow and develop, soil fertility decreases due to nutrient exports (COUTINHO et al. 2019). Among the various solutions to this problem, there is the application of the elements nitrogen $(\mathrm{N})$, phosphorus $(\mathrm{P})$ and potassium $(\mathrm{K})$ in the soil through fertilization. These nutrient macros, commonly known as NPK, are extremely important nutrients for the development of all organisms, especially soil and plants, being referred to as 'the three essential elements' in agriculture due to their critical role in crop production (YAN et al., 2020).

Nitrogen is essential for the production of chlorophyll, as well as an essential element for enzymatic proteins in plants, which catalyze and regulate the biological process responsible for their growth; phosphorus stimulates the growth of plant roots, therefore, di- 
Investigation of internal flow of Cryogenic injection

rectly interferes in their development; potassium is one of the nutrients necessary for photosynthesis in plants, also responsible for regulating water levels and $\mathrm{CO}_{2} \mathrm{ex}-$ change, as well as producing and transporting sugar, starch and proteins, helping in leaf growth and fruit quality (LASKAR; MUKHERJEE, 2016).

\section{Contextualization about NPK Sensors}

The use of sensors, ranging from manual data collectors to satellite images, has opened up some new possibilities for fine-tuning nutrient applications, it is known that new fertilizer formulas and various additives have created a variety of options with which Farmers and their consultants can develop an integrated nutrient management plan, especially in the manufacturing and handling process, are available on the market, in addition to monitors and sensors for adjusting the fertilizer application rates, and various analytical processes for Accessing soil nutrient availability and plant contents are part of a set of technologies used to increase efficiency in the use of fertilizers (REETZ Jr. 2016).

The determination of the concentrations of NPK present in the soil is necessary for the correction of such levels in order to obtain greater soil efficiency and crop productivity (COUTINHO et al. 2019). In addition, there are some techniques for measuring NPK. The most conventional technique is physical-chemical analysis in the laboratory. Despite producing good results, it becomes impracticable for precision in fertilization, since it does not present results quickly and at low cost, and can harm agricultural activity (LASKAR; MUKHERJEE, 2016, COUTINHO et al., 2019).

Based on this problem, techniques and technologies for measuring NPK have been developed in recent years. The main developed techniques described in the literature involve one of the following methods:

- Optical sensing: which detects the levels of energy reflected / absorbed by the nutrients existing in the soil by means of reflectance spectroscopy; and,

- Electrochemical sensing: which detects the selected ions by means of the current or voltage they generate as a result of using selective ion electrodes (LASKAR; MUKHERJEE, 2016, RAMANE; PATIL; SHALIGRAM, 2015; COUTINHO et al., 2019; LAVANYA; RANI; GANESHKUMAR, 2020).

These techniques are applied to the development of technologies for measuring NPK, sensors (RAMANE;
PATIL; SHALIGRAM, 2015; LAVANYA; RANI; GANESHKUMAR, 2020). However, there are few studies on the development of these sensors in the literature. Consequently, there is a need to assess the scenario in which the NPK sensors developed to date are inserted in order to contribute to the knowledge in this area of study. One of the ways to carry out such an evaluation is through the information contained in the patent documents, the objective of this article.

\section{Patent Documents}

According to the international patent system, the detailed technical description of the invention, novelty, inventive step and industrial application must be present in the patent documents. However, these documents are used, in addition to scientists and industry technicians, by companies in corporate processes or marketing, in risk analysis and strategic planning studies and in research and development activities. For this reason, patent documents are a rich source of technological information (MARTINEZ; SANTOS; WINTER, 2015).

Nowadays the focus is on methods to extract technological "expertise"from databases, both printed and digital, in order to capture and disseminate the technological information necessary for decision making through strategic planning. Enabling the identification of technological opportunities, practically addressing items that can affect the survival and future growth of the business (BUZZANGA, 2008).

Regarding legal validity, patent documents can be classified into:

(i) patent application documents; and,

(ii) patents, that is, patent documents granted.

The first concept refers to documents when it is presented for the first time to a patent office, while the second concept is attributed to the title granted by the State to the inventors or authors or other natural or legal persons with rights over the creation of the invention, during the period of its validity (INPI, 2018).

Most patent offices use the International Patent Classification (IPC), a unique system for encoding letters and numbers in which patent documents are grouped according to the technical areas to which they belong. At IPC patent documents are organized, allowing easy access to the technological and legal information contained therein. The most current versions of the IPC 
Investigation of internal flow of Cryogenic injection

can be accessed in English on the WIPO ${ }^{1}$ and when translated into Portuguese on the INP ${ }^{2}$ (WIPO, 2018).

Based on what was exposed in the previous paragraphs, this article aims, through the monitoring of patent documents, to carry out the patent mapping of NPK sensors and their applications, especially for use in biofertilizer, in order to contribute for the development and dissemination of information about this area of study that is so little explored in the literature.

\section{Methodology}

This article uses the patent mapping methodology, which was carried out in four stages: 1st stage: defining the search criteria, 2nd stage: carrying out the search, 3rd stage: selecting the patent documents referring to the NPK sensors used to measure fertilizers, and 4th step: treat the data.

The 1st stage: defining the search criteria consisted of defining the following search criteria: (a) scope of the search: without restriction; (b) database; Espacenet (free database of the European Patent Office, (c) definition of the technology (NPK sensor used to dose fertilizers: IPC (the following subclasses were used: A01C21, A01C23, C05F, C05G, G01D21, G01N21, G01N23, G01N27, G01N33, G01N37, G05B19) combined with the following keywords, with truncation (Sens * OR sensing OR detect * OR Measurement OR assessment OR monitoring) AND (NPK OR (Nitrogen AND Potassium AND Phosph)); and, (d) period: without period restriction.

In the 2nd stage: perform the search with the criteria defined in the 1st stage.

In the 3rd stage: reading the patent document and select the patent documents referring to the NPK sensor used to measure fertilizers from the data obtained in the search for the 2nd stage.

In the 4th stage, the data selected in the 3rd stage were treated in such a way that from the patent documents were obtained: the temporal evolution, the main technologies, the main priority countries; and, the main depositors.

$1 /$ https://www.wipo.int/classifications/ipc/ipcpub/?notion= scheme\&version=20200101\&symbol=none\&menulang=en\&lang= en $\&$ viewmode $=f \&$ fipcpc $=$ no\&showdeleted $=$ yes $\&$ indexes $=$ no \& headings=yes \&notes=yes \&direction=o 2 n\&initial=A\&cwid=none $\&$ tree $=$ no\&searchmode $=$ smart $>$

${ }^{2}<$ http://ipc.inpi.gov.br/classifications/ipc/ipcpub/?notion= scheme\&version=20200101\&symbol=none\&menulang=pt\&lang= pt\&viewmode $=$ f\&fipcpc $=$ no\&showdeleted $=$ yes \&indexes $=$ no $\&$ headings=yes\&notes=yes \&direction=o2n\&initial=A\&cwid=none \& tree $=$ no\&searchmode $=$ smart $>$

\section{Results and discussion}

Using the methodology explained above, in step 2 (search) 341 patent documents were obtained, after reading the abstracts 95 patent documents were considered relevant, that is, there are 95 patent documents referring to NPK sensors used to measure fertilizers.

After reading and analyzing the abstracts of these 95 patent documents, these documents were divided according to the location that the sensor is placed in: soil and bio digester (46 patent documents, equivalent to $48 \%$ ); bio digester only (22 patent documents, equivalent to $23 \%$ ); only on the ground (17 patent documents, equivalent to $18 \%$ ); plants and / or vegetables (9 patent documents, equivalent to $9 \%$ ); e, water (1 patent documents, equivalent to 1\%); as shown in Figure 1 .

In addition, the documents were divided according to the patent document's focus on: application (68 patent documents, equivalent to $72 \%$ ); development (18 patent documents, equivalent to $19 \%$ ); and others (9 patent documents, equivalent to 9\%); as shown in Figure 2.

In Figure 1, a concentration of publications can be seen from 2012 with a peak between 2014 and 2019 (shown in detail in Figure 3). The patent documents for sensors placed in the soil and bio digester were published in 2009 and at the peak between 2012 and 2019; the documents referring only to bio digester were published in 1980, 2020, 2008, 2012 and at the peak between 2015 to 2020 ; the documents referring only to the soil were published in 2003, 2008 and at the peak between 2014 and 2020; the documents referring to plants and / or vegetables were published in 2012 and at the peak between 2014 and 2018; and, the water document was published in 2018.

With the growing demand for fertilizers in Brazil, since the global crisis in 2008, sales have increased at an average rate of $8.6 \%$ per year in the country. In 2013 , fertilizer deliveries to the final consumer totaled 31.08 million tons. With the current demand for fertilizers in the world is approximately 182 million tons, according to a survey made by the GlobalFert Portal, nitrogen $(\mathrm{N})$ is the most consumed nutrient in all agricultural production, which is led $(60 \%)$ by China, India, United States and Brazil. China, with almost 1.4 billion inhabitants, is the largest consumer of $\mathrm{N}$ nutrients, phosphorus $(\mathrm{P})$ and potassium $(\mathrm{K})$. India is the second largest consumer of $\mathrm{N}$ and $\mathrm{P}$ and the fourth $\mathrm{K}$ due to the low concentration of nutrients in Indian soil. The USA, one of the world's leading suppliers of food, fuel and fiber, is the third largest consumer of $\mathrm{N}$ and the fourth largest consumer of 
Investigation of internal flow of Cryogenic injection

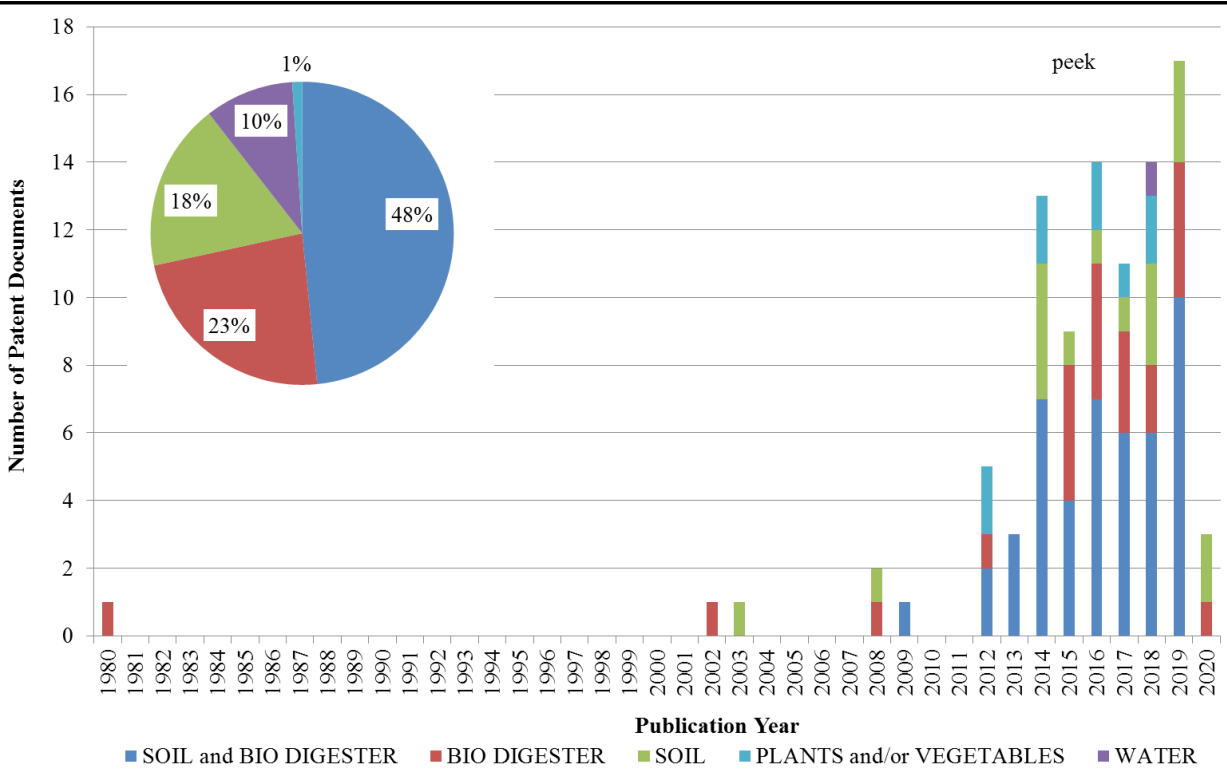

Figure 1: Temporary evolution of the publication of patent documents regarding the NPK sensors used to measure fertilizers in relation to where the sensor is placed.

Source: Prepared by the Authors from the Espacenet patent base (2020).

$\mathrm{P}$ and $\mathrm{K}$. Brazil, an agricultural superpower due to the abundance of land and water, is the fourth largest consumer of $\mathrm{N}$ and the third of $\mathrm{P}$. Because it has soils with $\mathrm{K}$ deficiency, it is the second largest consumer of the nutrient. However, its production of the product represents only $2 \%$ of the world production of fertilizers, as can be seen in Figure 2 below, thus becoming one of the largest importers of the product (LOBO, 2008).

In 2016 Brazil was the largest importer of fertilizers, and right after that we have the United States and India. Brazil was responsible for US\$ 6 million, the United States for US\$ 5.7 and India for US\$ 4.5 million (SILVA; FERNANDES, 2015). The two main ports that receive Brazilian imports are those of Paranaguá and Santos, where only the port of Paranaguá received from January to October 20178.4 billion tons of fertilizers by sea, that is, an amount of US\$ 2.2 billion. The port of Santos is soon receiving 3.6 billion tons of fertilizers, equivalent to US\$943 million during the same period.

In 2017, the Brazilian trade balance of fertilizers showed an increase throughout the year, as shown in Figure 3 below. This is a consequence of the production of commodities in the country, and imports this year are ten times higher than exports, thus generating a negative balance (SILVA; FERNANDES, 2015).
Figure 2 shows the time evolution of the publication of patent documents for NPK sensors used to measure fertilizers in relation to the focus of the patent document, it is observed a concentration of publications from 2012 with a peak between 2014 and 2019 Patent documents with an application focus were published in 2003 and peaked between 2014 and 2020; development-focused documents were published in 2008, 2009 and peaked between 2012 and 2019; and, the documents with a focus on others were published in 1980, 2002 and at the peak between 2012 to 2014, and, 2017. It should also be noted that the main focus of the invention described in the patent documents is on the application (68 patent documents, equivalent to $72 \%$ ), that is, to properly apply (in correct quantity) NPK fertilizers to the soil in order to improve the quality soil, thus allowing cultivation in so-called poor soils.

Figure 3 shows the detail of the peak growth of the publication of patent documents referring to the NPK sensors used to measure fertilizers, that is, the detail of the peak of figures 1 and 2 in the same figure. At the peak, patent documents refer to:

(a) sensors placed on the ground and bio digester whose documents focus on the application (32 patent documents); 
Investigation of internal flow of Cryogenic injection

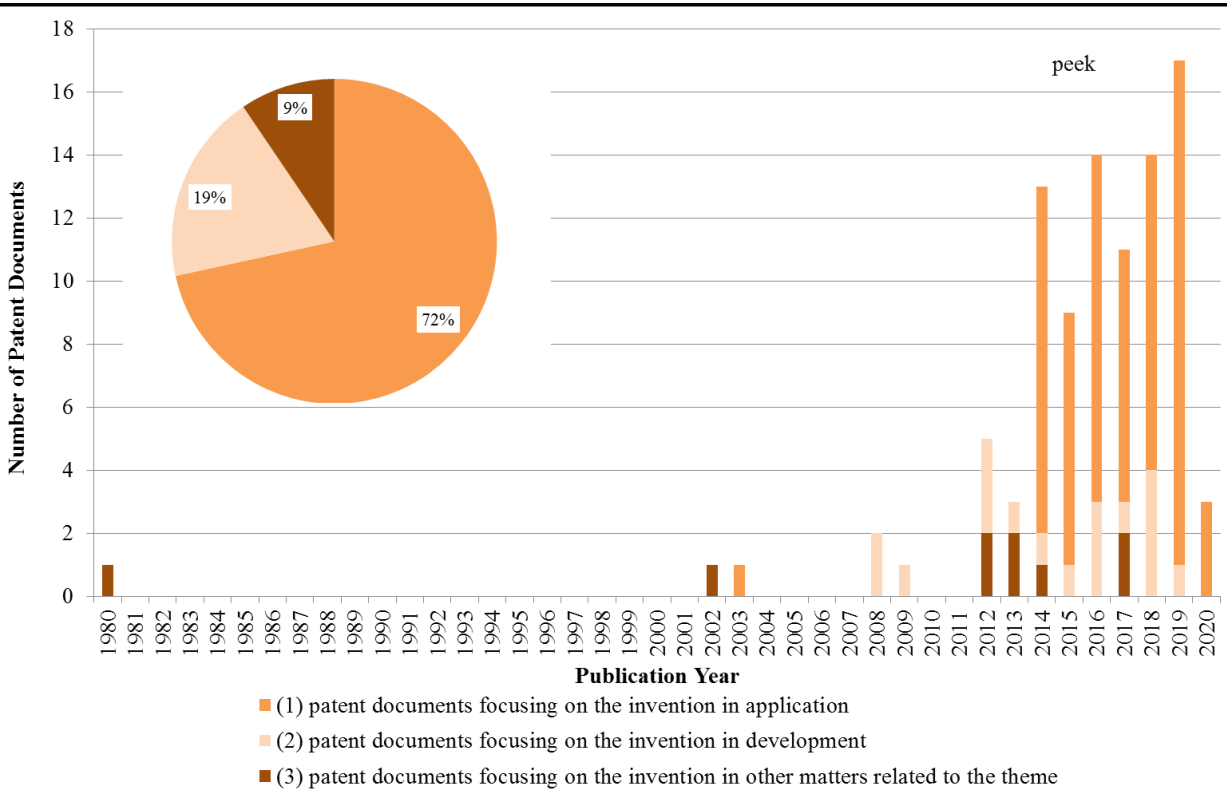

Figure 2: Time evolution of the publication of patent documents regarding NPK sensors used to measure fertilizers in relation to the focus of the patent document.

Source: Prepared by the Authors from the Espacenet patent base (2020).

(b) sensors placed only in the bio digester whose documents are focused on the application (15 patent documents); and,

(c) sensors placed only on the ground whose documents are focused on the application (11 patent documents).

Reinforcing what was presented that the main focus of the invention described in the patent documents is in the application of sensors in the soil and bio digester (32 patent documents, equivalent to $34 \%$ ) in order to apply the correct amount of NPK fertilizers in the soil thus improving soil quality.

Figure 4 refers to the country of priority of the patent documents referring to the NPK sensors used to measure fertilizers, it can be seen that $96 \%$ of the documents originate in China and that only a single patent document has two Chinese priority documents . In addition, patent documents referring to NPK sensors used to measure fertilizers are protected only in their country of origin (priority country), indicating that there is no interest in protecting this technology in other countries. This behavior in China, is especially due to the fact that investments in research and development in the study of fertilizers, and their respective intellectual property protection measures, as noted at Jiangsu University, are directly due to the fact that in Jiangsu, the regional difference in fertilizer application and environmental risk assessment was affected by many factors, including physical and economic conditions, government policy, management system, technology and management methods (LIU, 2015).

Furthermore, according to data from Our World in Data (2020), China is the country that consumes the most NPK fertilizers per hectare, it is the largest producer and consumer of NPK fertilizers, one reason is the fact that the soil Chinese is poor in nutrients, mainly low in NPK.

With regard to IPC subclasses as the first classification of patent documents referring to NPK sensors used to measure fertilizers, as shown in Figure 5, the main IPC subclasses are related to fertilizers $(45 \%)$, with emphasis on $\mathrm{G} 01 \mathrm{~N}$ referring to research or analysis of materials by determining their chemical or physical properties (24 patent documents, equivalent to $25 \%$ of the total); or, the measurement (34\%), with emphasis on: A01C referring to planting, sowing, fertilization (20 patent documents, equivalent to $21 \%$ of the total), and, $\mathrm{C} 05 \mathrm{G}$ referring to mixtures of fertilizers, mixtures of one or more fertilizers with additives that have no 


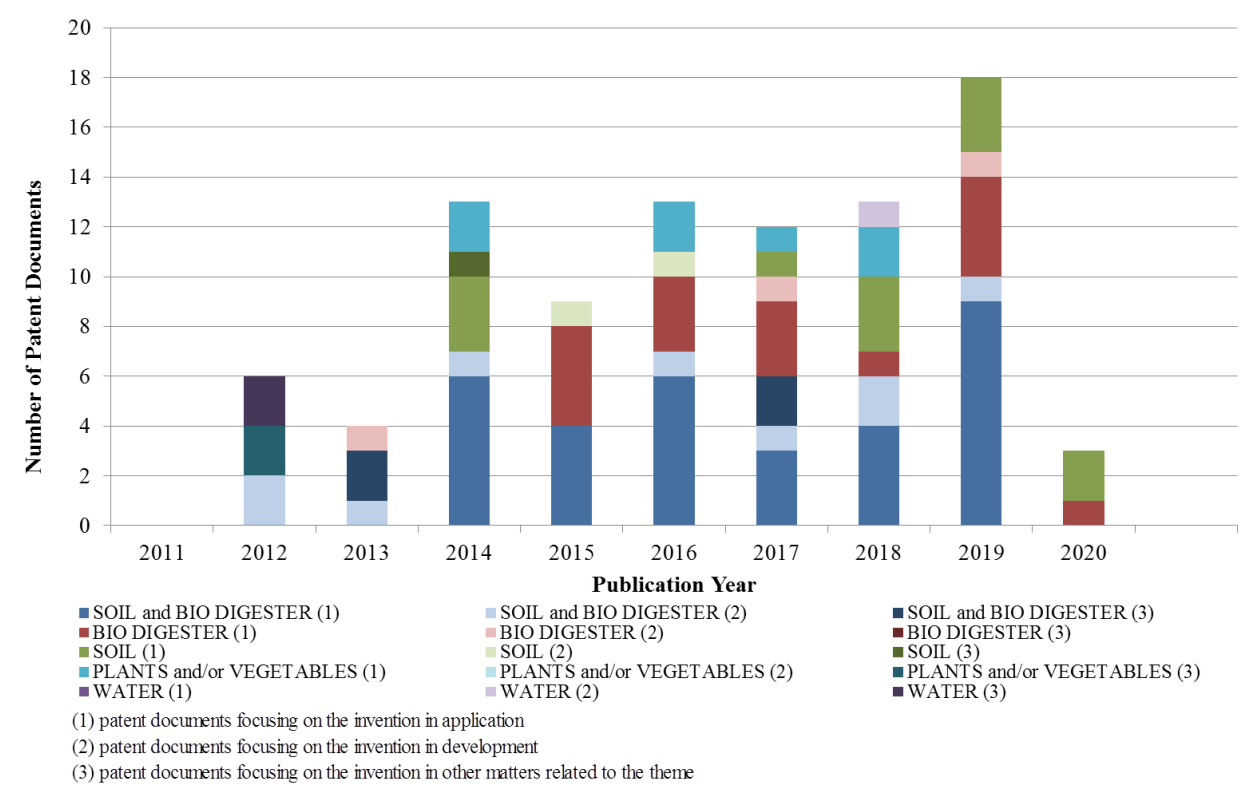

Figure 3: Time evolution of the publication of patent documents regarding the NPK sensors used to measure fertilizers in relation to where the sensor is placed during the peak period (2014 to 2019).

Source: Prepared by the Authors from the Espacenet patent base (2020).

mumber of documents with a single priority document

number of documents with two priority documents

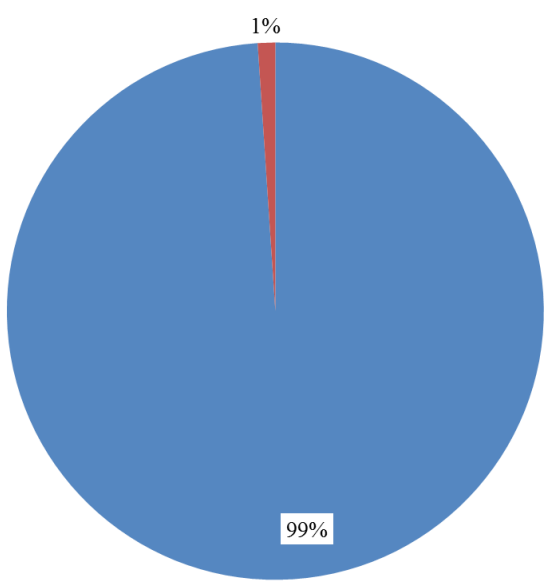

Priority Country

$\square$ China $\backsim$ Australia $\square$ Germany $\square$ Japan $\amalg$ Philippines

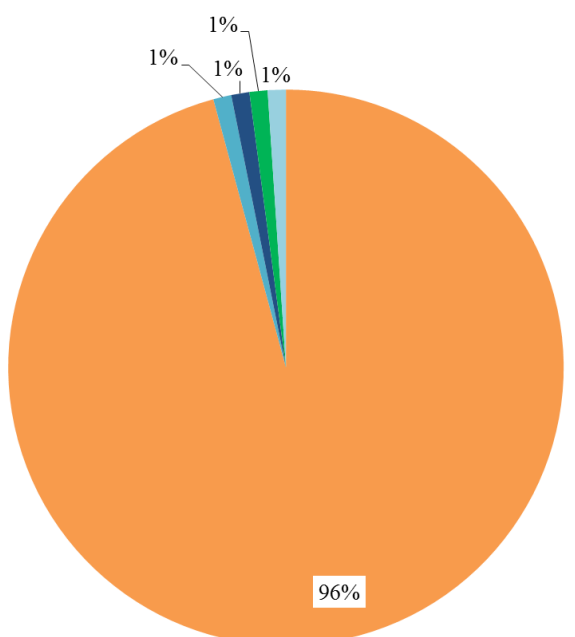

Figure 4: Countries of origin of patent documents referring to NPK sensors used to measure fertilizers in relation to the focus of the patent document.

Source: Prepared by the Authors from the Espacenet patent base (2020). 
Investigation of internal flow of Cryogenic injection

specifically fertilizing activity; fertilizers characterized by their shape (14 patent documents, equivalent to $15 \%$ of the total). In addition, it was found that 64 patent documents, equivalent to $67 \%$ of the total, had the classifications defined in the methodology as the first classification of the patent document; Among the classifications that are not in the methodology, the following stand out: G01N1 referring to sampling; preparation of specimens for investigation (5 patent documents, equivalent to $5 \%$ of the total); and, A01G9 referring to the cultivation in receptacles, greenhouses or greenhouses, borders for beds, lawns or similar (4 patent documents, equivalent to $4 \%$ of the total), emphasizing that these main classifications are also also related to the application of fertilizer. NPK, and these classifications contain documents that are written with a focus on the application of fertilizers as a soil correction factor.

As shown in Figure 6, depositors are distributed in a non-concentrated manner, 75 depositors have only one patent document deposited (equivalent to 86\%), 7 depositors have two patent documents deposited (equivalent to $8 \%$ ), 3 depositors have four patent documents deposited (equivalent to $4 \%$ ), and 2 depositors have six patent documents deposited (equivalent to $2 \%$ ). Regarding the nature of the depositor, there is a predominance of legal entities (companies) with 49 patent documents (equivalent to $43 \%$ ), and universities, research institutes and the like with 43 patent documents (equivalent to 38\%).

Among the depositors, we highlight: (a) Ding Yulan - Chinese inventor (with 6 patent documents referring to NPK sensors used to measure fertilizers placed in the soil and bio digester); and, (b) Jiangsu University - Chinese university (with 6 patent documents referring to NPK sensors used to measure fertilizers placed on plants and / or vegetables); as can be seen in Figure 7 Researcher and inventor Ding Yulan in partnership with Jiangsu University, carry out measurement studies in both soil and biomanager, this is because in Jiangsu, the regional difference in fertilizer application and evaluation of Environmental risk was affected by many factors, including physical and economic conditions, government policy, management system, technology and management methods.

\section{Conclusion}

With the elaboration of this work, it was demonstrated that a process of management and technological monitoring by patent documents, can be very opportune for, for example, technologies that involve the impro- vement of the process or the final product of precision agriculture when we use sensors to supply information that can generate correction and better efficiency of the soil with adjustments of NPK fertilizers, mainly due to the potential and content of strategic information contained in these documents.

From the universe of 341 patent documents obtained in this study and their respective analysis, 95 patent documents were considered relevant regarding the NPK sensors used to measure fertilizers. With this new segmentation it was understood that of the 95 documents, the focus was on its application, thus finding $66 \%$ of documents with the presence of sensors both on the ground and in the bio manager. These patent documents referring to sensors placed in the soil and bio digester peaked between 2012 and 2019, which clearly contrasts with the growing demand for fertilizers in Brazil, since the global crisis in 2008.

Macroeconomic factors and the constant increase in the need for agricultural production make innovation follow these indicators together, according to a survey by the GlobalFert Portal, nitrogen $(\mathrm{N})$ is the most consumed nutrient in all agricultural production, which is led China (60\%), India, United States and Brazil. Again, China, with almost 1.4 billion inhabitants, is the largest consumer of NPK fertilizers, followed by India, USA and Brazil.

It should also be noted that the main focus of the invention described in the patent documents is on the application (68 patent documents, equivalent to $72 \%$ ), that is, to properly apply (in correct quantity) NPK fertilizers to the soil in order to improve the quality of the soil, thus allowing cultivation in so-called poor soils. This behavior in China is especially due to the fact that investments in research and development in the study of fertilizers, and their respective intellectual property protection measures, are noted in Jiangsu University, it is directly due to the fact that in Jiangsu, the regional difference in fertilizer application and environmental risk assessment was affected by many factors, including physical and economic conditions, government policy, management system, technology and management methods, China is the largest consumer of NPK per hectare.

In addition to the above, we have researcher and inventor Ding Yulan in partnership with Jiangsu University, where they carry out and reinforce measurement studies both in soil and in bio-management, this is because in Jiangsu, the regional difference in fertilizer application and evaluation of Environmental risk 


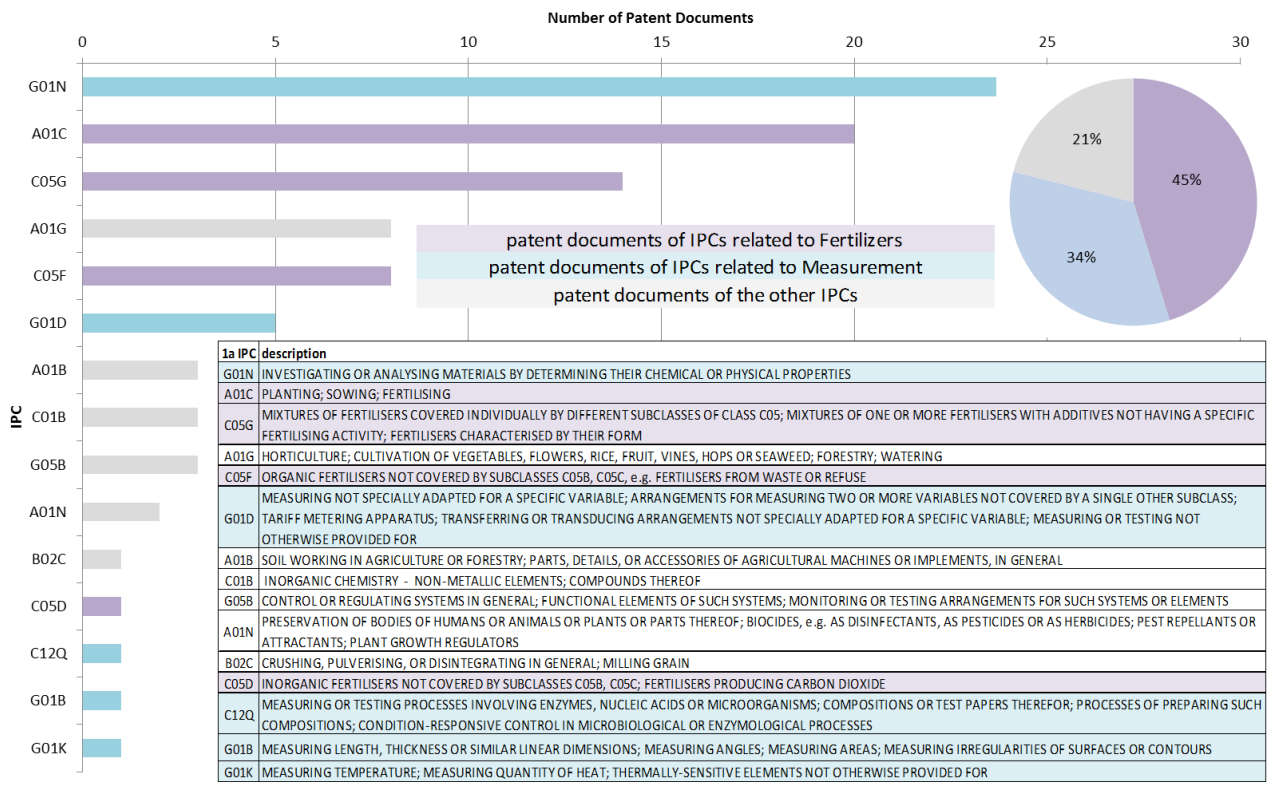

Figure 5: Subclasses of IPC as first classification of patent documents referring to NPK sensors used to measure fertilizers.

Source: Prepared by the Authors from the Espacenet patent base (2020).

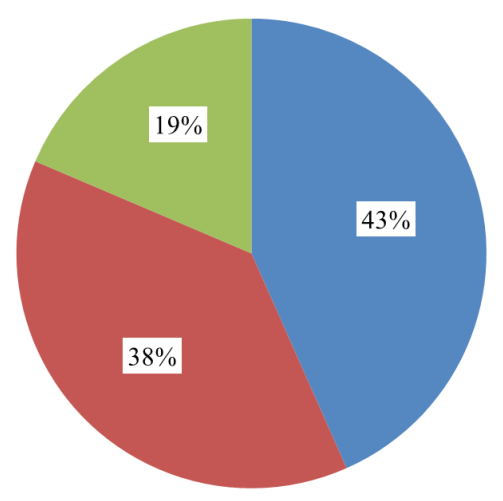

- Pessoa Jurídica

Universidade, Institutos de Pesquisa e afins Inventor Independente

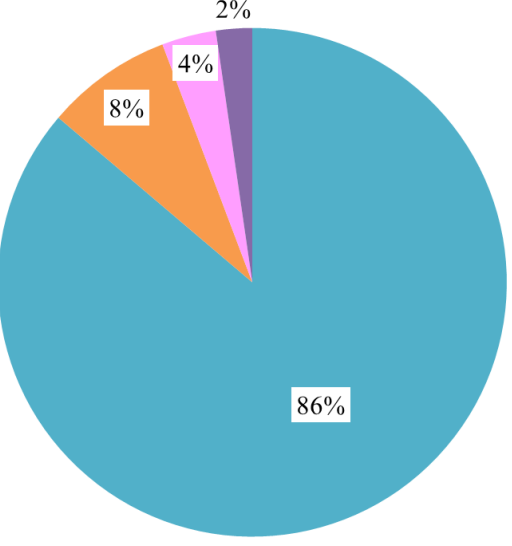

- depositantes com somente um documento patentário

depositantes com dois documentos patentários

depositantes com quatro documentos patentários

- depositantes com seis documentos patentários

Figure 6: Information from depositors of patent documents regarding the NPK sensors used to measure fertilizers in relation to the focus of the patent document.

Source: Prepared by the Authors from the Espacenet patent base (2020). 
Investigation of internal flow of Cryogenic injection

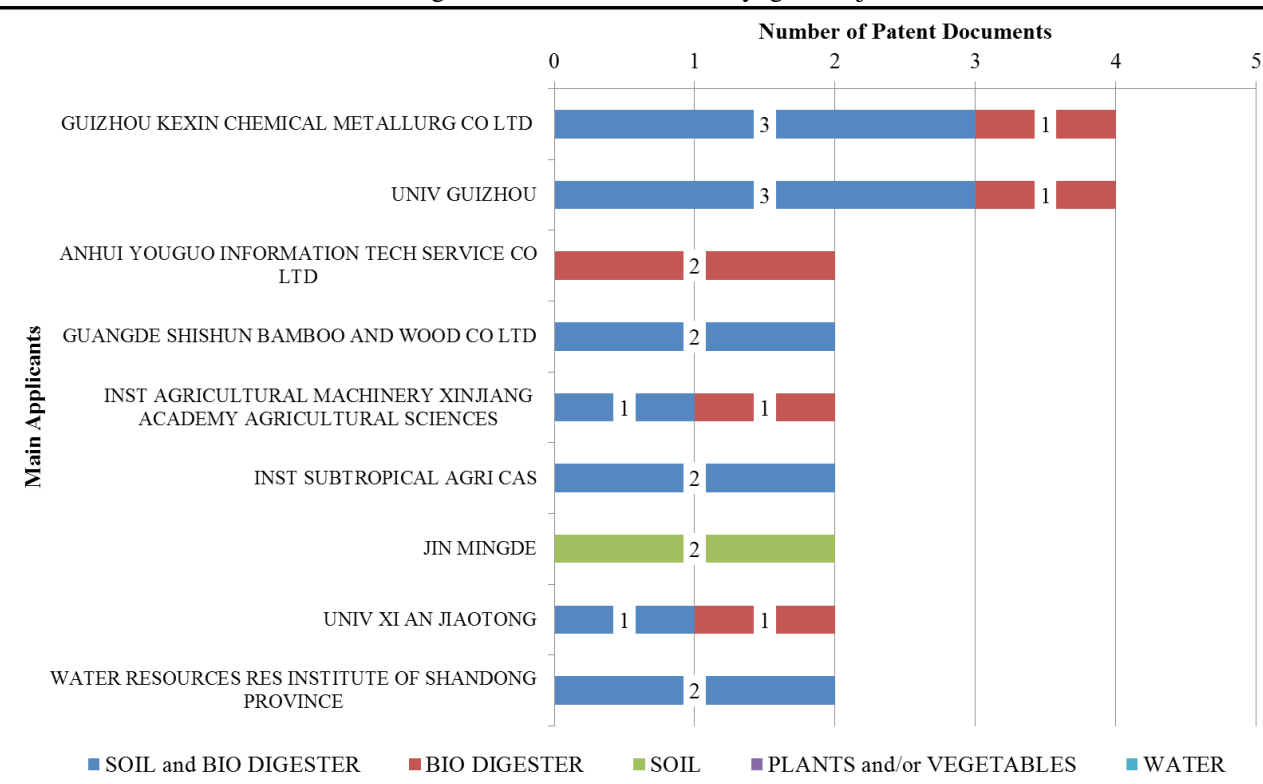

Figure 7: Main depositors of patent documents referring to NPK sensors used to measure fertilizers in relation to the focus of the patent document.

Source: Prepared by the Authors from the Espacenet patent base (2020).

was affected by many factors, including physical and economic conditions, government policy, management system, technology and management methods.

The conclusion of this study on the innovation process in precision agriculture using patent mapping using npk sensors in the production of fertilizers was that technology is at its peak of development and the largest number of patent documents refers to the application of sensors in the soil and bio digester (34\%) in order to apply the correct amount of NPK fertilizers in the soil thus improving soil quality ant it is being developed mainly in China.

\section{References}

AMARAL, L. R. d.; MOLIN, J. P. Sensor óptico no auxílio à recomendação de adubação nitrogenada em cana-de-açúcar. Pesquisa Agropecuária Brasileira, SciELO Brasil, v. 46, n. 12, p. 1633-1642, 2011.

BUZZANGA, J. Using Technology intelligence for R\&D. 2008. Disponível em: <http: //www.industryweek.com/articles/using_technology_ intelligence_for_rd_17162.aspx> . Acesso em: 18 set. 2020.
COUTINHO, M. A.; ALARI, F. d. O.; FERREIRA, M. M.; AMARAL, L. R. do. Influence of soil sample preparation on the quantification of npk content via spectroscopy. Geoderma, Elsevier, v. 338, n. 1, p. 401-409, 2019.

INPI. Instituto Nacional de Propriedade Industrial. 2018. Disponível em: <http://www.inpi.gov.br> Acesso em: 18 set. 2020.

LASKAR, S.; MUKHERJEE, S. Optical sensing methods for assessment of soil macronutrients and other properties for application in precision agriculture: a review. ADBU Journal of Engineering Technology, v. 4, n. 1, p. 206-210, 2016.

\section{LAVANYA, G.; RANI, C.; GANESHKUMAR, P.}

An automated low cost iot based fertilizer intimation system for smart agriculture. Sustainable Computing: Informatics and Systems, Elsevier, v. 28, n. 1, p. 100300, 2020.

LIU, Q. Regional difference of npk fertilizers application and environmental risk assessment in jiangsu province, china. Ying yong sheng tai xue bao= The journal of applied ecology, v. 26, n. 5, p. 1477-1483, 2015. 
Investigation of internal flow of Cryogenic injection

LOBO, V. O mercado e o desafio da indústria de fertilizantes no Brasil. Palestra no INSTITUTO BRASILEIRO DE MINERAÇÃO (IBRAM). 2008. Disponível em: <http://www.ibram.org.br/cbminas/ palestras/25_11_00_Vicente\%20Lobo.pdf> Acesso em: 24 out. 2020 .

LOPES, D.; LOWERY, S.; PEROBA, T. L. C. Crédito rural no brasil: desafios e oportunidades para a promoção da agropecuária sustentável. BNDES, Banco Nacional de Desenvolvimento Econômico e Social, v. 45 , n. 1, p. 155-196, 2016.

MARTINEZ, M. E. M.; SANTOS, D. A.; WINTER, E. Mapeamento por meio de documentos patentários depositados no brasil das tecnologias do setor de celulose e papel. O Papel, São Paulo, v. 76, n. 10, p. 77-81, 2015.

RAMANE, D. V.; PATIL, S. S.; SHALIGRAM, A. D. Detection of npk nutrients of soil using fiber optic sensor. In: International Journal of Research in Advent Technology Special Issue National Conference ACGT 2015. [S.1.: s.n.], 2015. p. 66-70.

REETZ Jr, H. F. Fertilizers and their efficient use. 1. ed. Paris, France, 2016.

SILVA, L. A.; FERNANDES, N. M. A cadeia produtiva de adubos e fertilizantes. In: Encontro Científico de Gestão Portuária. Santos: Anais do II Encontro Científico de Gestão Portuária: Redes de Empresas e Cadeias Produtivas, 2015. v. 1, n. 1, p. 1-15.

WIPO. WIPO REFORMED IPC. 2018. Disponível em: $<$ http://www.wipo.int/ipcpub/\#lang=en\&refresh= page> Acesso em: 19 set. 2020.

YAN, S.; WU, Y.; FAN, J.; ZHANG, F.; ZHENG, J.; QIANG, S.; GUO, J.; XIANG, Y.; ZOU, H.;

WU, L. Dynamic change and accumulation of grain macronutrient ( $\mathrm{n}, \mathrm{p}$ and $\mathrm{k}$ ) concentrations in winter wheat under different drip fertigation regimes. Field Crops Research, Elsevier, v. 250, n. 1, p. 107767, 2020. 